\title{
Antireceptor Antibodies as Probes of Insulinlike Growth Factor Receptor Structure
}

\author{
Masato Kasuga, Norio Sasaki, C. Ronald Kahn, S. Peter Nissley, and \\ MATTHEW M. ReChleR, Elliott P. Joslin Research Laboratory, Joslin Diabetes \\ Center and Department of Medicine, Brigham and Women's Hospital, \\ Harvard Medical School, Boston, Massachusetts 02115; Section on \\ Biochemistry of Cell Regulation, Laboratory of Biochemical Pharmacology, \\ National Institute of Arthritis, Diabetes, and Digestive and Kidney Diseases, \\ and Metabolism Branch, National Cancer Institute, National Institutes of \\ Health, Bethesda, Maryland 20205
}

A B S T R A C T Insulin receptors and Type I insulinlike growth factor (IGF) receptors have a similar structure with a major binding subunit of $M_{r} \sim 130,000$ linked by disulfide bonds to other membrane proteins to form a $M_{\mathrm{r}}>300,000$ complex. Both insulin and Type I IGF receptors also interact with both insulin and IGF, although with different binding affinities. We used a panel of human and rabbit sera containing antibodies to insulin receptors to determine whether these sera also interact with Type I IGF receptors. Immunoglobulins from five of five human sera inhibited binding of ${ }^{125} \mathrm{I}$-insulin and ${ }^{125} \mathrm{I}$-IGF-I to insulin receptors and Type I IGF receptors in human placenta and human lymphocytes. The rank order of reactivity with both receptors was the same; two sera, however, appeared to be selectively less reactive with the Type I IGF receptor, especially in placenta.

Sera from five of seven patients and from a rabbit immunized with purified insulin receptor effectively immunoprecipitated both placental insulin receptors and Type I IGF receptors. Of the remaining sera, one had only a low titer against the insulin receptor and did not immunoprecipitate the IGF receptor, whereas the second serum effectively immunoprecipitated crosslinked and surface-iodinated insulin receptors, but had negligible reactivity against the Type I IGF receptor. These results suggest that most antisera to the insulin

This work was presented in part at the 64th Annual Meeting of the Endocrine Society, June 1982, San Francisco, CA.

Dr. Kasuga's present address is Third Department of Internal Medicine, Faculty of Medicine, University of Tokyo, Tokyo, Japan. Address reprint requests to Dr. Rechler, NIH, Building 4, Room Bl-14, Bethesda, MD 20205.

Received for publication 15 April 1983. receptor also contain antibodies to Type I IGF receptors. Whether both specificities are inherent in the same or different antibody molecules remains to be determined. These data support the hypothesis that the insulin and IGF-I receptors are separate but related molecules, although there remains a small possibility that both receptors are domains on the same protein.

\section{INTRODUCTION}

Insulinlike growth factor (IGF) ${ }^{1}$-I and IGF-II are closely related polypeptides purified from human plasma that have major amino acid sequence homologies to human proinsulin $(1,2)$. Like insulin and other polypeptide hormones, IGF-I and IGF-II initiate their biological actions by being recognized by specific receptors on the surface of responsive target tissues. At least two subtypes of IGF receptors can be distinguished by their relative reactivity with IGF-I and IGF-II and by their ability to interact with insulin (3, 4). In addition, the IGFs exhibit weak cross-reactivity with insulin receptors, as reflected by inhibition of ${ }^{125} \mathrm{I}$ insulin binding in competitive binding experiments $(5,6)$.

Recently, we and others have reported that two types of IGF receptor structures can be demonstrated by affinity labeling techniques $(7,8)$ and that the differences in receptor subunit organization correlated perfectly with the previously observed differences in the specificity of binding $(9,10)$. Type I IGF receptors

\footnotetext{
${ }^{1}$ Abbreviations used in this paper: BBS, borate-buffered saline; DSS, disuccinimidyl suberate; DTT, dithiothreitol; IGF, insulinlike growth factor; MSA, multiplication-stimulating activity; PMSF, phenylmethylsulfonyl fluoride.
} 
react preferentially with IGF-I compared with IGFII, but they also interact with high concentrations of insulin. Type I IGF receptor complexes have an apparent $M_{\mathrm{r}}$ of $\sim 130,000$ under reducing conditions and $>300,000$ without reduction, suggesting that a $M_{\mathrm{r}}$ $\sim 130,000$ receptor subunit is disulfide-linked to itself or other membrane proteins in the native state. The Type II IGF receptor reacts preferentially with IGFII compared with IGF-I, but does not appear to bind insulin, even at high concentrations. Type II IGF receptor complexes have an apparent $M_{\mathrm{r}}$ of $\sim 220,000$ before reduction and $M_{\mathrm{r}}$ of $\sim 260,000$ after reduction, suggesting that they contain internal disulfide bonds, but that they are not linked by disulfide bridges to other membrane proteins. The structure of Type I, but not Type II, IGF receptors is quite similar to that determined for insulin receptors by similar affinity labeling techniques, ${ }^{2}$ although the two receptors can be distinguished by the relative abilities of insulin and IGF to inhibit the binding of the labeled ligands $(9,10,12-16)$.

The marked similarity of the Type I IGF receptor and the insulin receptor raised the question whether the IGF-I and insulin binding sites might represent different domains on the same $M_{\mathrm{r}} \sim 130,000$ protein, or whether they are present on separate but highly homologous structures. To address this question, we used sera from a group of patients with the Type B syndrome of extreme insulin resistance and acanthosis nigricans that are known to possess circulating autoantibodies to insulin receptors (17). These polyclonal immunoglobulins inhibit insulin binding and immunoprecipitate insulin receptors from a variety of tissues and species (11). We examined the ability of these autoantibodies, as well as a rabbit antiserum to the insulin receptor, to inhibit binding to and immunoprecipitate Type I IGF receptors.

\section{METHODS}

\section{Cell cultivation}

IM-9 cells, an established line of human lymphoblasts (18), were obtained from S. Taylor (Diabetes Branch, National Institutes of Health) and R. G. Rosenfeld (Stanford University, Stanford, CA) and propagated in continuous suspension culture at $37^{\circ} \mathrm{C}$ in RPMI 1640 medium (Gibco Laboratories, Grand Island, NY) supplemented with $10 \%$ (vol/vol) fetal bovine serum (Reheis Chemical Co., Phoenix, AZ).

BRL 3A2 cells, a cloned line of rat liver cells, were grown in monolayer culture in a humidified incubator $\left(37^{\circ} \mathrm{C}, 5 \%\right.$ $\mathrm{CO}_{2}$ ) in modified Ham's F12 medium containing 5\% (vol/ vol) fetal bovine serum as previously described (4).

\footnotetext{
${ }^{2}$ By experimental techniques other than affinity cross-linking, a second subunit of $M_{\mathrm{r}} 90,000$ has also been identified in insulin receptors (11).
}

Fao rat hepatoma cells, a clonal line of well-differentiated rat hepatoma cells derived from the Reuber H-35 hepatoma (19), were maintained in monolayer culture in modified Ham's F12 medium supplemented with $5 \%$ fetal bovine serum.

\section{Human placental membranes}

A crude membrane fraction containing microsomal and plasma membranes $(100,000-g$ pellet) was prepared from normal human fresh-frozen full-term placentae, as described previously (20).

\section{Summary of receptor preparations used in this study}

The distribution of insulin receptors and Type I and Type II IGF receptors on human placental membranes, IM-9 lymphoblasts, Fao hepatoma cells, and BRL 3A2 cells is summarized in Table $\mathrm{I}$.

\section{Peptides}

Porcine insulin (lot 1JM95AN) was purchased from Elanco Products Co., (Indianapolis, IN). IGF-I (16SPII) purified from human plasma (1) was a generous gift of René E. Humbel (Biochemisches Institut der Universität Zürich, Switzerland). A partially purified preparation (No. 1932) of IGF having a specific insulinlike activity of $36 \mathrm{mU} / \mathrm{mg}$ in the fat pad bioassay was used for some experiments where indicated. Multiplication-stimulating activity (MSA) II-1 ( $\mathbf{M}_{r}$ 8,700 ) from serum-free culture medium conditioned by the BRL $3 \mathrm{~A}$ cell line was purified by Dowex chromatography, Sephadex G-75 gel filtration, and preparative electrophoresis as previously described (22). ${ }^{125} \mathrm{I}$-Insulin, ${ }^{125} \mathrm{I}-\mathrm{IGF}-\mathrm{I}$, and ${ }^{125} \mathrm{I}-$ MSA were prepared by the stoichiometric chloramine $\mathrm{T}$ procedure as previously described $(4,13)$.

\section{TABLE I}

Distribution of Insulin Receptors and IGF Receptors in Placenta, Lymphoblasts, and Hepatocytes

\begin{tabular}{lccc}
\hline \multicolumn{1}{c}{ Cell or membrane preparation } & $\begin{array}{c}\text { Insulin } \\
\text { receptors }\end{array}$ & $\begin{array}{c}\text { Type I IGF } \\
\text { receptors }\end{array}$ & $\begin{array}{c}\text { Type II IGF } \\
\text { receptorst }\end{array}$ \\
\hline $\begin{array}{l}\text { Human placental membranes } \\
\text { Human lymphoblast cell line }\end{array}$ & + & + & \pm \\
$\begin{array}{l}\text { (IM-9) } \\
\text { Rat hepatoma cell line (Fao)§ }\end{array}$ & + & + & - \\
Rat liver cell line (BRL 3A2) & - & - & + \\
\hline
\end{tabular}

- Identified with ${ }^{125}$ I-IGF-I. Inhibition by IGF-I > IGF-II $>$ insulin. After DSS cross-linking, $M_{\mathrm{r}}>300,000$ (nonreduced), $\sim 130,000$ (reduced).

$\ddagger$ Identified with ${ }^{125}$ I-MSA or ${ }^{125}$ I-IGF-II. Inhibition by IGF-II > IGF-I; no inhibition by insulin. After DSS cross-linking, $M_{\mathrm{r}}$ $\sim 220,000$ (nonreduced), $\sim 260,000$ (reduced).

$\S$ The Fao cell line is a subclone of the Reuber H35 cell line and exhibits the same receptor distribution (reference 21 and Kasuga, M., unpublished results). 


\section{Antibodies to the insulin receptor}

Sera containing autoantibodies to the insulin receptor were obtained from Type B patients with extreme insulin resistance and acanthosis nigricans (17) after an overnight fast, heated to $56^{\circ} \mathrm{C}$ for $30 \mathrm{~min}$, and stored at $-20^{\circ} \mathrm{C}$. Patients were designated B-2 (J.P.), B-3 (O.G.), B-4 (O.B.), B-5 (J.R.), B-6 (D.H.), B-8 (H.H.), and B-9 (M.C.) as previously described $(23,24)$. Rabbit serum (A410) containing antiinsulin receptor antibody that had been raised by immunization of rabbits with purified insulin receptor of rat liver (25) was kindly provided by Dr. Steven J. Jacobs (Wellcome Research Laboratories, Research Triangle Park, NC).

\section{Isolation of IgG}

IgG fractions from control and patients' sera were isolated with protein A-Sepharose by a modification of the method of Ey et al. (26). $1 \mathrm{ml}$ of each serum was applied to a column containing $1 \mathrm{~g}$ protein A-Sepharose CL-4B (gel vol of $2 \mathrm{ml}$ ) equilibrated with borate-buffered saline (BBS), pH 8.5 (50 $\mathrm{mM}$ boric acid, $120 \mathrm{mM} \mathrm{NaCl}, 0.02 \%$ sodium azide). The flow-through was reapplied to the column. Then, the column was washed with $20 \mathrm{ml}$ of BBS. The IgG was eluted with 4 $\mathrm{ml} 0.1 \mathrm{M}$ sodium citrate/citric acid buffer, $\mathrm{pH}$ 3.0. The eluate was dialyzed overnight against BBS and stored at $4^{\circ} \mathrm{C}$. Protein concentrations of isolated IgG were calculated from the absorbance at $280 \mathrm{~nm}$, assuming an extinction coefficient $(1 \% \mathrm{wt} / \mathrm{vol}, 1 \mathrm{~cm})$ of 14 . Yields of $\mathrm{IgG}$ ranged from 3.4 to $18.6 \mathrm{mg} / \mathrm{ml}$.

\section{Reagents}

Reagents were purchased from the following sources: protein A-Sepharose, Pharmacia Fine Chemicals (Piscataway, NJ); Staphylococcus aureus protein A (Pansorbin), Calbiochem-Behring Corp., American Hoechst Corp. (Somerville, $\mathrm{NJ}$ ); $\mathrm{Na}{ }^{125} \mathrm{I}$, New England Nuclear (Boston, MA); disuccinimidyl suberate (DSS), Pierce Chemical Co. (Rockford, IL); reagents for sodium dodecyl sulfate (SDS)-gel electrophoresis, Bio-Rad Laboratories (Rockville Center, NY); glucose oxidase, Boehringer Mannheim Biochemicals (Indianapolis, IN); lactoperoxidase, Sigma Chemical Co. (St. Louis, MO).

\section{Binding assay conditions}

\section{HUMAN PLACENTAL MEMBRANES}

Competition-inhibition. Membranes were suspended in incubation buffer (50 mM Tris- $\mathrm{HCl}, 10 \mathrm{mM} \mathrm{MgCl}, 1 \mathrm{mg} /$ $\mathrm{ml}$ bovine serum albumin (BSA), $\mathrm{pH}$ 7.4). Membranes (50 $\mu \mathrm{g}$ in $0.1 \mathrm{ml}$ ) were preincubated with control or patients' IgG (aliquots brought to $0.1 \mathrm{ml}$ with BBS) for $5 \mathrm{~h}$ at $37^{\circ} \mathrm{C}$, washed three times with $2 \mathrm{ml}$ of incubation buffer $\left(4^{\circ} \mathrm{C}\right)$, and resuspended in buffer. ${ }^{125}$ I-Insulin $(40 \mathrm{pg})$ or ${ }^{125} \mathrm{I}$-IGFI $(250 \mathrm{pg})$ was added to give a final reaction volume of 0.5 $\mathrm{ml}$, and the incubation continued for $16 \mathrm{~h}$ at $4^{\circ} \mathrm{C}$. To terminate the reaction, $2 \mathrm{ml}$ of ice-cold buffer was added, and bound and free labeled peptides were separated by centrifugation $\left(1,000 \mathrm{~g}, 20 \mathrm{~min}, 4^{\circ} \mathrm{C}\right)$. The supernatant was aspirated, and membrane-associated radioactivity quantitated in a gamma counter $(27,28)$. Specific binding was calculated by subtracting the nonspecifically bound peptide from the total bound labeled peptide. Nonspecific binding was determined in the presence of an excess of unlabeled peptide (IGF, No. 1932, $36 \mathrm{mU} / \mathrm{mg}, 10 \mu \mathrm{g} / \mathrm{ml}$; insulin, $20 \mu \mathrm{g} / \mathrm{ml}$ ).
Binding, cross-linking, gel electrophoresis, and autoradiography. The crude membrane pellet was suspended in assay buffer (100 mM Hepes, $120 \mathrm{mM} \mathrm{NaCl}, 1.2 \mathrm{mM} \mathrm{MgSO}_{4}$, $2.5 \mathrm{mM} \mathrm{KCl}, 1 \mathrm{mM}$ EDTA, $10 \mathrm{mM}$ glucose, $1.5 \mathrm{mM}$ sodium acetate, $\mathrm{pH} 7.8$ ) containing $10 \mathrm{mg} / \mathrm{ml} \mathrm{BSA}$ at a membrane protein concentration of $1 \mathrm{mg} / \mathrm{ml}$. The membranes $(0.4 \mathrm{mg})$ were then incubated for $18 \mathrm{~h}$ at $4^{\circ} \mathrm{C}$ with $0.5-1.5 \mathrm{nM}{ }^{125} \mathrm{I}$ insulin or $2.5 \mathrm{nM}^{125}$ I-IGF-I in the absence and the presence of the indicated concentrations of unlabeled hormones or IgG. The incubation mixture was cooled to $4^{\circ} \mathrm{C}$, diluted threefold with assay buffer without BSA ( $\mathrm{pH} 7.4)$, and centrifuged at $4^{\circ} \mathrm{C}(5 \mathrm{~min}, 10,000 \mathrm{~g})$. The membrane pellet was resuspended in ice-cold assay buffer without BSA to a membrane protein concentration of $1 \mathrm{mg} / \mathrm{ml}$.

Cross-linking was performed as previously described (13). DSS, freshly dissolved in dimethyl sulfoxide, was added to a final concentration of $0.03 \mathrm{mM}$. After $15 \mathrm{~min}$, the reaction was quenched by addition of 5 vol ice-cold $10 \mathrm{mM}$ Tris- $\mathrm{HCl}$, $1 \mathrm{mM}$ EDTA, pH 7.4, and the mixture was centrifuged (5 min, $10,000 \mathrm{~g}$ ). The membrane pellet then was boiled for $2 \mathrm{~min}$ in $10 \mathrm{mM}$ sodium phosphate buffer, $\mathrm{pH} 7.0$, containing 2\% SDS and $100 \mathrm{mM}$ dithiothreitol (DTT), and the samples analyzed in $0.1 \%$ SDS- $7.5 \%$ polyacrylamide gels using a discontinuous buffer system (29). The gels were stained with $0.25 \%$ Coomassie Blue in $50 \%$ trichloroacetic acid, destained in $7 \%$ acetic acid, dried, and autoradiographed with Kodak X-Omat film (Eastman Kodak Co., Rochester, NY) using a DuPont Cronex Lightening Plus enhancing screen (DuPont Instruments, Wilmington, DE). The molecular weights of the standards are as follows: filamin, 250,000; myosin, 200,$000 ; \beta$-galactosidase, 116,000; phosphorylase b, 94,000; BSA, 68,000 ; and ovalbumin, 43,000 .

\section{HUMAN IM-9 LYMPHOBLASTS}

IM-9 cells in late log phase were sedimented and resuspended at a concentration of $5 \times 10^{7} / \mathrm{ml}$ in buffer $(100 \mathrm{mM}$ Hepes, $118 \mathrm{mM} \mathrm{NaCl}, 1.2 \mathrm{mM} \mathrm{MgSO} 4,5 \mathrm{mM} \mathrm{KCl}, 8.8 \mathrm{mM}$ dextrose, and $10 \mathrm{mg} / \mathrm{ml} \mathrm{BSA}, \mathrm{pH} 8.0)$. Cells $\left(2.5-5 \times 10^{6}\right.$ in $0.1 \mathrm{ml}$ ) were preincubated with control or patients' IgG (0.1 ml in BBS) for $2 \mathrm{~h}$ at $37^{\circ} \mathrm{C}$ (for IGF-I binding studies) or $22^{\circ} \mathrm{C}$ (for insulin binding studies). After preincubation, cells were sedimented and washed three times with $2 \mathrm{ml}$ phosphate-buffered saline (PBS) at $22^{\circ} \mathrm{C}$. Washed, resuspended cells $\left(2.5 \times 10^{6}\right)$ were incubated with ${ }^{125}$ I-insulin $(40$ pg) or ${ }^{125} \mathrm{I}-\mathrm{IGF}-\mathrm{I}(250 \mathrm{pg})$ in $0.5 \mathrm{ml}$ assay buffer for $2 \mathrm{~h}$ at $15^{\circ} \mathrm{C}$. At the end of the incubation, duplicate $200-\mu \mathrm{l}$ aliquots were layered onto $150 \mu \mathrm{l}$ ice-cold buffer in plastic microtubes and centrifuged at $10,000 \mathrm{~g}$ for $1 \mathrm{~min}$ in a Beckman microfuge (Beckman Instruments, Inc., Palo Alto, CA). Cell-associated radioactivity was determined by gamma counting. Nonspecific binding was determined as described for placental membranes.

\section{BRL 3A2 CELLS}

Binding of ${ }^{125} \mathrm{I}-\mathrm{IGF}-\mathrm{I}$ and ${ }^{125} \mathrm{I}-\mathrm{MSA}$ to confluent BRL $3 \mathrm{A2}$ cell monolayers was performed as previously described (7). Incubations were at $\mathrm{pH} 7.0$ in the Hepes binding buffer used with IM-9 lymphoblasts. Cross-linking and electrophoresis were performed as described above.

\section{Immunoprecipitation of cross-linked ligand- receptor complexes}

${ }^{125}$ I-IGF-I, ${ }^{125}$ I-insulin, or ${ }^{125}$ I-MSA were bound and crosslinked to human placental membranes or BRL $3 A 2$ cells as 
described above. The membranes or cells were then solubilized in $25 \mathrm{mM}$ Hepes buffer containing $1 \%$ Triton X-100, aprotinin ( 1 trypsin inhibitor unit/ml), and phenylmethylsulfonyl fluoride (PMSF) $(2 \mathrm{mM})$ for $30 \mathrm{~min}$ at room temperature. The preparation was centrifuged at $200,000 \mathrm{~g}$ for $60 \mathrm{~min}$ at $4^{\circ} \mathrm{C}$ and the insoluble pellet discarded. Solubilized ${ }^{125}$ I-labeled hormone-receptor complexes were incubated in $25 \mathrm{mM}$ Hepes buffer, $\mathrm{pH} 7.4$, overnight at $4^{\circ} \mathrm{C}$ with the indicated concentrations of serum containing antiinsulin receptor antibody or control serum. Protein A (Pansorbin 10\% [vol/vol] solution) (100-200 $\mu \mathrm{l})$ was added and, after a further incubation for $1 \mathrm{~h}$ at $4^{\circ} \mathrm{C}$, the mixture was centrifuged and washed three times with $25 \mathrm{mM}$ Hepes buffer containing $0.1 \%$ Triton. The radioactivity in the pellets was counted in a gamma counter. Alternatively, the pellets were dissolved in $10 \mathrm{mM}$ sodium phosphate buffer containing $2 \%$ SDS and $100 \mathrm{mM}$ DTT and subjected to electrophoresis and autoradiography as described above.

\section{Surface labeling of hepatoma cell line (Fao)}

Confluent Fao cells (five 100-mm dishes, $2-4 \times 10^{7}$ cells/ dish) were washed three times with Dulbecco's PBS and surface iodinated as previously described (30). The reaction was carried out in $3 \mathrm{ml} \mathrm{PBS} / \mathrm{dish}$, which contained $20 \mathrm{mM}$ glucose, $1 \mathrm{mCi}$ of $\mathrm{Na}{ }^{125} \mathrm{I}, 2 \mathrm{mg}$ lactoperoxidase, and was initiated by adding glucose oxidase $(200 \mathrm{mU} / \mathrm{ml})$. After $30 \mathrm{~min}$ at room temperature, the cells were washed three times with cold PBS and solubilized for $30 \mathrm{~min}$ at room temperature in $25 \mathrm{mM}$ Hepes buffer containing 1\% Triton X-100, PMSF $(2 \mathrm{mM})$, and aprotinin (l trypsin inhibitor unit $/ \mathrm{ml}$ ). Insoluble material was removed by centrifugation at $100,000 \mathrm{~g}$ for $60 \mathrm{~min}$ at $4^{\circ} \mathrm{C}$. The supernatant was immunoprecipitated as described above.

\section{RESULTS}

Subunit structure of insulin receptors and IGF-I receptors in human placental membranes. Human placental membranes possess specific receptors for insulin and for IGF-I (Table I). The two receptors can be distinguished in competitive binding studies by preferential inhibition of labeled ligand binding by the homologous unlabeled ligand (31). Both receptors also interact with the heterologous ligand at high concentrations.

The nature of the receptor proteins that bind ${ }^{125} \mathrm{I}-$ insulin and ${ }^{125}$ I-IGF-I was examined by covalently coupling bound radioligand with the bifunctional reagent DSS and by examining the solubilized receptor complexes by SDS-polyacrylamide gel electrophoresis and autoradiography. When examined under reducing conditions, both ${ }^{125} \mathrm{I}$-insulin (Fig. 1) and ${ }^{125} \mathrm{I}$-IGF-I (Fig. 2) appeared in $M_{r} \sim 130,000$ complexes. The $M_{r}$ $\sim 130,000{ }^{125}$ I-insulin complex was identified as a component of the insulin receptor, since its formation was preferentially inhibited by addition of unlabeled insulin to the binding incubations, and only weakly inhibited by unlabeled IGF-I (Fig. 1). The $M_{\mathrm{r}}$ $\sim 130,000{ }^{125}$ I-IGF-I complex was identified as a component of the IGF-I receptor by virtue of inhibition of its formation by low concentrations of unlabeled IGF-I and considerably higher concentrations of unlabeled insulin (Fig. 2). In the absence of disulfide reduction, both the ${ }^{125}$ I-insulin and ${ }^{125}$ I-IGF-I labeled complexes had $M_{\mathrm{r}}>300,000$, suggesting that the $M_{\mathrm{r}}$ $\sim 130,000$ binding subunits were disulfide linked to other membrane proteins (not shown). Similar results have been reported by other investigators using other IGF-I-like polypeptides (basic somatomedin [14] and somatomedin $C$ [15]) as radioligands and either affinity cross-linking [15] or photoaffinity labeling [14].

Inhibition of ${ }^{125} I-$ insulin and ${ }^{125} I-I G F-I$ binding to human placental membrane and BRL $3 A 2$ rat liver cell receptors by antiinsulin receptor antibody from patient B-2. Patients with extreme insulin resistance and acanthosis nigricans (Type B) possess circulating autoantibodies directed against insulin receptors (17). Patient B-2 has one of the highest titers of these antibodies, and hence her serum and IgG have been used extensively in studies of the insulin receptor (11). In addition, we previously have shown that Fab fragments prepared from IgG B-2 inhibited ${ }^{125}$ I-IGF-I binding to cultured human fibroblasts (32).

The ability of IgG B-2 to inhibit ${ }^{125} \mathrm{I}$-insulin and ${ }^{125} \mathrm{I}$ IGF-I binding to placental membranes is compared in Fig. 3. Radioligand was incubated with membranes in the presence of 0,10 , and $100 \mu \mathrm{g} / \mathrm{ml}$ of IgG B-2. Bound radioactivity was cross-linked with DSS and examined by SDS-polyacrylamide gel electrophoresis under reducing conditions. IgG B-2 inhibited the for-

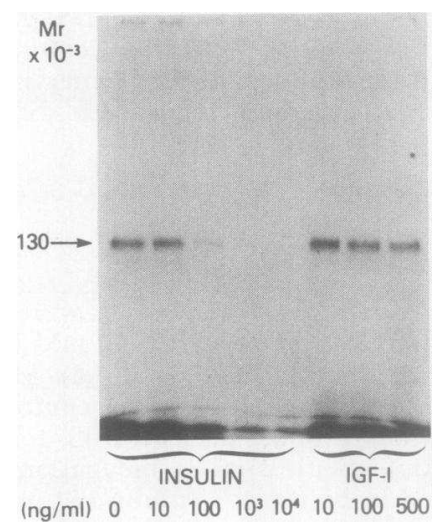

Figure 1 Autoradiogram showing the specificity of ${ }^{125} \mathrm{I}$ insulin receptor complexes cross-linked to human placental membranes and examined under reducing conditions. $\mathrm{Hu}-$ man placental membranes $(400 \mu \mathrm{g})$ were incubated with ${ }^{125} \mathrm{I}-$ insulin $(1 \mathrm{nM})$ in the absence and in the presence of several concentrations of insulin and IGF-I as described in Methods. Cross-linking with DSS, solubilization in 2\% SDS containing $100 \mathrm{mM}$ DTT, electrophoresis, and autoradiography were as described in Methods. The position of the $M_{r} \sim 130,000$ receptor complex is indicated by an arrow. 


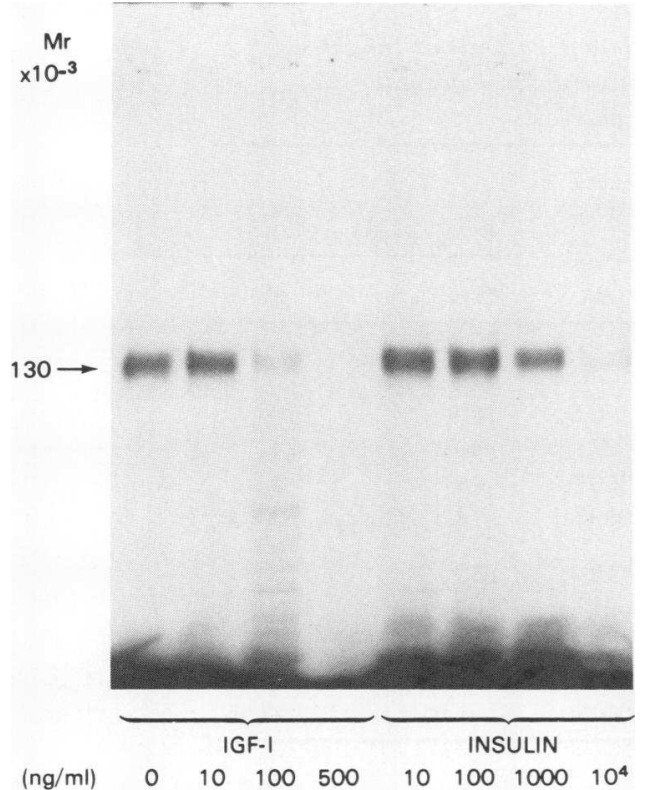

FIgURE 2 Autoradiogram showing the specificity of ${ }^{125} \mathrm{I}$ IGF-I receptor complexes cross-linked to human placental membranes and examined under reducing conditions. $\mathrm{Hu}$ man placental membranes $(400 \mu \mathrm{g})$ were incubated with ${ }^{125} \mathrm{I}$ IGF-I $(2 \mathrm{nM})$ in the absence and in the presence of several concentrations of IGF-I and insulin as described in Methods. Cross-linking with DSS, solubilization in 2\% SDS containing $100 \mathrm{mM}$ DTT, electrophoresis, and autoradiography were as described in Methods. The position of the $M_{\mathrm{r}} \sim 130,000$ receptor complex is indicated by an arrow. The point designated $500 \mathrm{ng} / \mathrm{ml}$ of IGF-I represents incubation with $4 \mu \mathrm{g} / \mathrm{ml}$ of a one-eighth pure preparation (No. 1932; 36 $\mathrm{mU} / \mathrm{mg}$ ).

mation of both $M_{\mathrm{r}} \sim 130,000$ insulin receptor and IGF-I receptor complexes in dose-dependent fashion. By contrast, the same concentrations of IgG B-2 failed to inhibit the formation of $M_{\mathrm{r}} \sim 130,000$ IGF-I receptor complexes in the BRL 3A2 rat liver cell line (Fig. 3), despite the fact that BRL $3 \mathrm{~A} 2$ and placental IGF-I receptors exhibit similar reactivity with IGF-I, IGF-II, and insulin $(4,31)$. This suggests that IgG B2 may react specifically with human IGF-I receptors.

Inhibition of ${ }^{125}$ I-insulin and ${ }^{125}$ I-IGF-I binding to human placental membranes and human IM-9 lymphoblasts by IgG from patients $B-5, B-6, B-8$, and $B-$ 9. IgG from four other type $B$ patients were examined for their ability to inhibit ${ }^{125}$ I-insulin and ${ }^{125}$ I-IGF-I binding to human placental membranes (Fig. 4). Membranes were preincubated with the indicated concentrations of IgG for $5 \mathrm{~h}$ at $37^{\circ} \mathrm{C}$. IgG from patients B5 , B-8, B-9, and B-6 (in order of potency) gave dosedependent inhibition of ${ }^{125}$ I-insulin binding, whereas control IgG was without effect (right panel). Under the assay conditions used, maximal inhibition was $\sim 60 \%$.
Preincubation of placental membranes with two of these IgG preparations, B-5 and B-8, also resulted in an inhibition of ${ }^{125}$ I-IGF-I binding with a similar concentration dependence (left panel), although maximal inhibition of ${ }^{125} \mathrm{I}-\mathrm{IGF}-\mathrm{I}$ binding was only $\sim 30 \%$. By contrast, IgG from patients B-9 and B-6 were considerably less effective as inhibitors of ${ }^{125}$ I-IGF-I binding than ${ }^{125}$ I-insulin binding. Based on the relative concentrations of IgG required to inhibit ${ }^{125} \mathrm{I}$-insulin and ${ }^{125}$ I-IGF-I binding by $50 \%$, we estimate that IgG B-9 and B-6 were eight- to 10 -fold less effective as inhibitors of IGF-I binding than insulin binding (Table II).

Similar experiments were performed in human IM9 lymphoblasts and yielded similar results (Fig. 5). ${ }^{125} \mathrm{I}$ Insulin binding was inhibited $>90 \%$ by IgG B-2, B-5, and B-8, and less completely by IgG B-9 and B-6, in order of potency. IgG B-2, B-5, and B-8 also inhibited ${ }^{125}$ I-IGF-I most effectively, producing 70-90\% inhibition at $300 \mu \mathrm{g} / \mathrm{ml}$. As in placental membranes, IgG B-9 and B-6 were less effective inhibitors of ${ }^{125}$ I-IGF$I$ binding to lymphoblasts, producing 30 and $0 \%$ inhibition, respectively, at $300 \mu \mathrm{g} / \mathrm{ml}$.

These results indicate a striking parallelism of inhibitory potencies of IgG B-2, B-5, B-8, B-9, and B-6 toward insulin receptors and IGF-I receptors in both placenta and lymphoblasts. IgG B-9 and B-6 appear

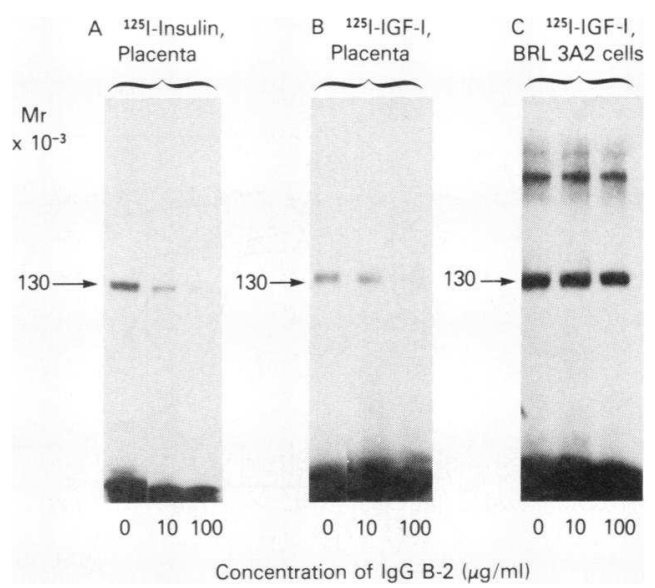

FigURE 3 Autoradiogram showing the inhibition of binding of ${ }^{125} \mathrm{I}$-insulin and ${ }^{125} \mathrm{I}$-IGF-I to human placental membranes and BRL $3 \mathrm{~A} 2$ cells by antiinsulin receptor antibody (IgG B-2). Human placental membranes $(A$ and $B$ ) and BRL $3 A 2$ cells $(C)$ were incubated with ${ }^{125} \mathrm{I}$-insulin $(A)$ or ${ }^{125} \mathrm{I}-\mathrm{IGF}$-I $(B$ and $C$ ) in the presence of 0,10 , or $100 \mu \mathrm{g} / \mathrm{ml}$ of antiinsulin receptor antibody (IgG B-2). Cross-linking with DSS, solubilization in $2 \%$ SDS containing $100 \mathrm{mM}$ DTT, electrophoresis, and autoradiography were as described in Methods. The higher molecular weight complex observed in panel $C$ $\left(M_{\mathrm{r}} \sim 260,000\right)$ includes both $M_{\mathrm{r}} \sim 130,000$ Type I IGF receptor complexes cross-linked to itself or other membrane proteins, and Type II IGF receptor complexes (7). 
TABLE II

Relative Potencies of IgG from Serum of Different Patients as Inhibitors of ${ }^{125}$ I-Insulin and ${ }^{125}$ I-IGF-I Binding to Human Placental Membranes and IM-9 Lymphoblasts

\begin{tabular}{|c|c|c|c|c|c|}
\hline \multirow[b]{2}{*}{ Receptor preparation } & \multirow[b]{2}{*}{ Patient } & \multicolumn{2}{|c|}{$\begin{array}{l}\text { IgG concentration required } \\
\text { for half-maximal inhibition } \\
\text { of binding } \\
\end{array}$} & \multicolumn{2}{|c|}{ Potency relative to $\operatorname{lgG}$ B-5 $5^{\circ}$} \\
\hline & & ${ }^{128}$ I-Insulin & ${ }^{188}$ I-IGF-I & ${ }^{128}$ I-Insulin & ${ }^{128}$ I-IGF-I \\
\hline & & \multicolumn{2}{|c|}{$\mu g / m l$} & \multicolumn{2}{|c|}{$\%$} \\
\hline \multirow[t]{4}{*}{ Placental membranes $₫$} & B-5 & 4.8 & 6.5 & 100 & 100 \\
\hline & B-8 & 12 & 27 & 40 & 24 \\
\hline & B-9 & 25 & 350 & 19 & 2 \\
\hline & B-6 & 100 & $1,000 \S$ & 4.8 & 0.6 \\
\hline \multirow[t]{5}{*}{ IM-9 Lymphoblasts" } & B-2 & 7.5 & 12 & 253 & 175 \\
\hline & B-5 & 19 & 21 & 100 & 100 \\
\hline & B-8 & 30 & 60 & 63 & 35 \\
\hline & B-9 & 200 & 600 & 9.5 & 3.5 \\
\hline & B-6 & $1,000 \$$ & $>2,000 \pi$ & $1.9 \S$ & $<1 \pi$ \\
\hline
\end{tabular}

- Potency $=\mathrm{ED}_{50} \mathrm{~B}-5 / \mathrm{ED}_{50}$ experimental $\times 100$.

† Results from Fig. 4.

$\$$ Extrapolated.

"Results from Fig. 5.

II Estimated. No inhibition at $300 \mu \mathrm{g} / \mathrm{ml}$.

to be disproportionately less reactive with IGF-I receptors than insulin receptors, although the differences are quantitatively more impressive in placenta than in IM-9 lymphoblasts. These differences, like the differences in the maximum extent of inhibition by antibody in the two cell types, may reflect minor het-

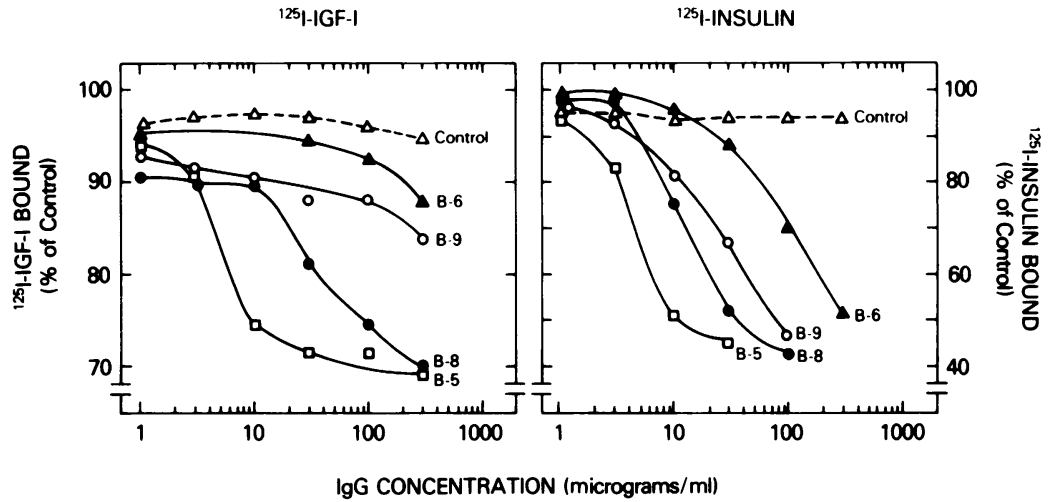

FIGURE 4 Inhibition of ${ }^{125}$ I-IGF-I and ${ }^{125}$ I-insulin binding to human placental membranes by IgG prepared from the serum of different patients. Membranes were preincubated with the indicated concentrations of IgG (from patients B-5, B-6, B-8, B-9, or from a control subject) for $5 \mathrm{~h}$ at $37^{\circ} \mathrm{C}$. After extensive washing, membranes were incubated with ${ }^{125} \mathrm{I}-\mathrm{IGF}-\mathrm{I}$ (left) or ${ }^{125} \mathrm{I}$-insulin (right) for $16 \mathrm{~h}$ at $4^{\circ} \mathrm{C}$, and membrane-bound radioactivity was determined as described in Methods. Results are expressed as percentage of specific binding to control membranes not preincubated with IgG. For ${ }^{125}$ I-IGF-I, total binding and specific binding were 18 and $16 \%$ of input radioactivity, respectively. For ${ }^{125} \mathrm{I}$-insulin, total binding and specific binding were 22 and $18 \%$ of input radioactivity, respectively. The reason for the incomplete inhibition of insulin binding $(\sim 60 \%)$ and IGF-I binding $(\sim 30 \%)$ is not known. In preliminary experiments examining different conditions of preincubation with $300 \mu \mathrm{g} / \mathrm{ml}$ of IgG B-8 (i.e., 0-12 h at $4^{\circ}$, $22^{\circ}$, and $37^{\circ} \mathrm{C}$ ), maximal inhibition was observed with a 5 -h preincubation at $37^{\circ} \mathrm{C}$, the conditions used in these experiments. 
125|-IGF-I

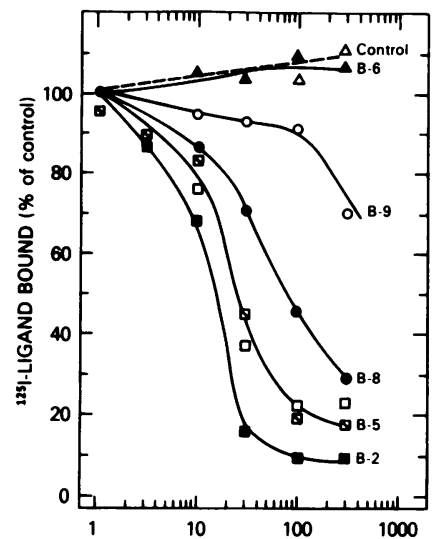

IgG CONCENTRATION (micrograms/ml)

FIgURE 5 Inhibition of ${ }^{125}$ I-IGF-I and ${ }^{125}$ I-insulin binding to human IM-9 lymphoblasts. The indicated concentrations of IgG prepared from control and patient's serum were preincubated with IM-9 lymphoblasts at $22^{\circ} \mathrm{C}$ (for insulin binding) or at $37^{\circ} \mathrm{C}$ (for IGF-I binding) for $2 \mathrm{~h}$. After washing, cells $\left(5-10 \times 10^{6} / \mathrm{ml}\right)$ were incubated with ${ }^{125}$ I-IGF-I (left) or ${ }^{125} \mathrm{I}$-insulin (right) for $2 \mathrm{~h}$ at $15^{\circ} \mathrm{C}$, and the cellbound radioactivity determined. Bound ${ }^{125} \mathrm{I}$-ligand is expressed as percentage of specific binding to control cells (not preincubated with IgG). For ${ }^{125}$ I-insulin, total and specific binding were 11.0 and $10.1 \%$. For ${ }^{125}$ I-IGF-I, results of two

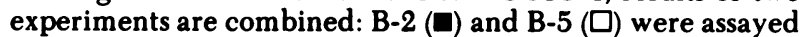
in one experiment, and B-5 $(\nabla), B-8, B-9, B-6$, and control IgG in a second experiment. For ${ }^{125} \mathrm{I}-\mathrm{IGF}-\mathrm{I}$, total and specific binding were 7.1 and $6.7 \%$ of input radioactivity, respectively, in the experiment with B-2 and B-5, and 5.5 and $4.9 \%$, respectively, in the experiment with B-5, B-8, B-9, and B-6.

erogeneity in the receptors and their environment in different tissues.

Immunoprecipitation of ${ }^{125}$ I-insulin and ${ }^{125} I-I G F$ receptor complexes in human placenta and BRL $3 A 2$ rat liver cells by antiinsulin receptor antibody from patient $B-2$. We next compared the ability of antiinsulin receptor antibody B-2 to immunoprecipitate solubilized placental insulin and IGF-I receptor complexes. ${ }^{125}$ I-Insulin and ${ }^{125}$ I-IGF-I were affinity crosslinked to placental membranes with DSS, the receptor solubilized and immunoprecipitated with serum from patient B-2 or control serum, and analyzed by SDSpolyacrylamide gel electrophoresis under reducing conditions. As seen in the autoradiogram in Fig. 6 (left panel), serum B-2, but not control serum, immunoprecipitated both the ${ }^{125}$ I-insulin receptor complexes and ${ }^{125}$ I-IGF-I receptor complexes.

Interestingly, serum B-2 also immunoprecipitated ${ }^{125}$ I-IGF-I receptor complexes from affinity cross-linked, solubilized BRL 3A2 rat liver cells (Fig. 6, right panel). Since serum B-2 did not inhibit ${ }^{125}$ I-IGF-I binding to this receptor (Fig. 3), this finding suggests that IgG B2 interacts with a site on the IGF receptor different from the peptide binding site. By contrast, serum B2 did not immunoprecipitate complexes of ${ }^{125}$ I-MSA cross-linked to the Type II IGF receptor of BRL 3A2 cells, suggesting that the reactive determinant was absent or masked in this receptor subtype. This is consistent with our previous studies, which showed that antireceptor antibody B-2 did not inhibit ${ }^{125}$ I-MSA binding to a variety of rat and human Type II IGF receptors (9).

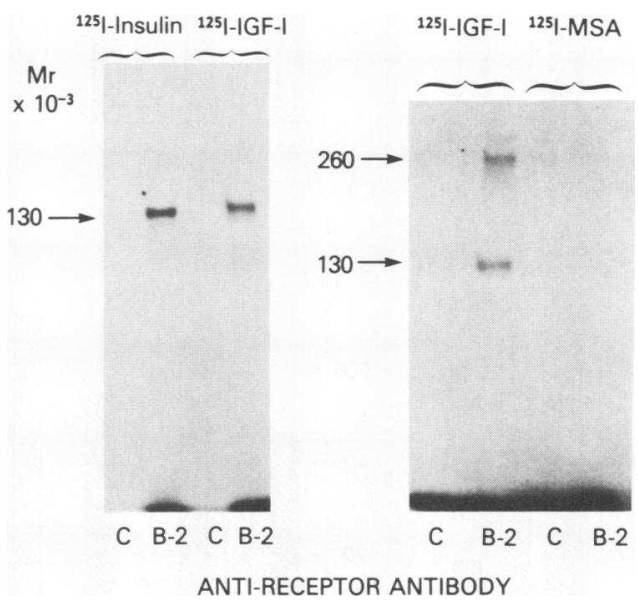

Figure 6 (Left) Autoradiogram showing the immunoprecipitation of ${ }^{125}$ I-insulin and ${ }^{125}$ I-IGF-I receptor complexes from human placental membranes by antiinsulin receptor antibody. Human placental membrane $(600 \mu \mathrm{g})$ were incubated with ${ }^{125}$ I-insulin and ${ }^{125}$ I-IGF-I, and affinity crosslinked by $0.03 \mathrm{mM}$ DSS as described above. After cross-linking, pellets were dissolved in $1 \mathrm{ml}$ of buffer containing 25 $\mathrm{mM}$ Hepes, $1 \%$ Triton X-100, PMSF, and aprotinin. After ultracentrifugation, $200 \mu \mathrm{l}$ ( ${ }^{125}$ I-insulin) or $400 \mu \mathrm{l}\left({ }^{125} \mathrm{I}\right.$-IGFI) of solubilized receptor were incubated with control serum (C) or serum containing antiinsulin receptor antibody $(B-2)$ at 1:200 dilution, and the immune complexes precipitated with protein A. Immunoprecipitates were washed, solubilized, and analyzed by SDS-polyacrylamide gel electrophoresis after reducing the disulfide bonds by DTT, and autoradiography. The position of $M_{\mathrm{r}} \sim 130,000$ receptor complexes is indicated. (Right) Autoradiogram showing the immunoprecipitation of ${ }^{125}$ I-IGF-I and ${ }^{125}$ I-MSA receptor complexes from BRL $3 \mathrm{~A} 2$ cells by antiinsulin receptor antibody (IgG B-2). BRL 3A2 cells were incubated with ${ }^{125}$ IIGF-I and ${ }^{125}$ I-MSA, cross-linked with DSS, and solubilized by Triton X-100. After centrifugation, aliquots of supernate were incubated with control $\operatorname{IgG}(C)$ or antiinsulin receptor IgG $(B-2)$ at the concentration of $100 \mu \mathrm{g} / \mathrm{ml}$, and precipitated with protein $A$. Immunoprecipitates were washed three times with $25 \mathrm{mM}$ Hepes buffer containing $0.1 \%$ Triton X100 , solubilized in the presence of $100 \mathrm{mM}$ DTT, and analyzed by SDS-polyacrylamide gel electrophoresis and autoradiography. The $M_{\mathrm{r}} \sim 260,000{ }^{125}$ I-IGF-I complex most likely represents $M_{\mathrm{r}} \sim 130,000$ complexes cross-linked to itself or other membrane proteins. 


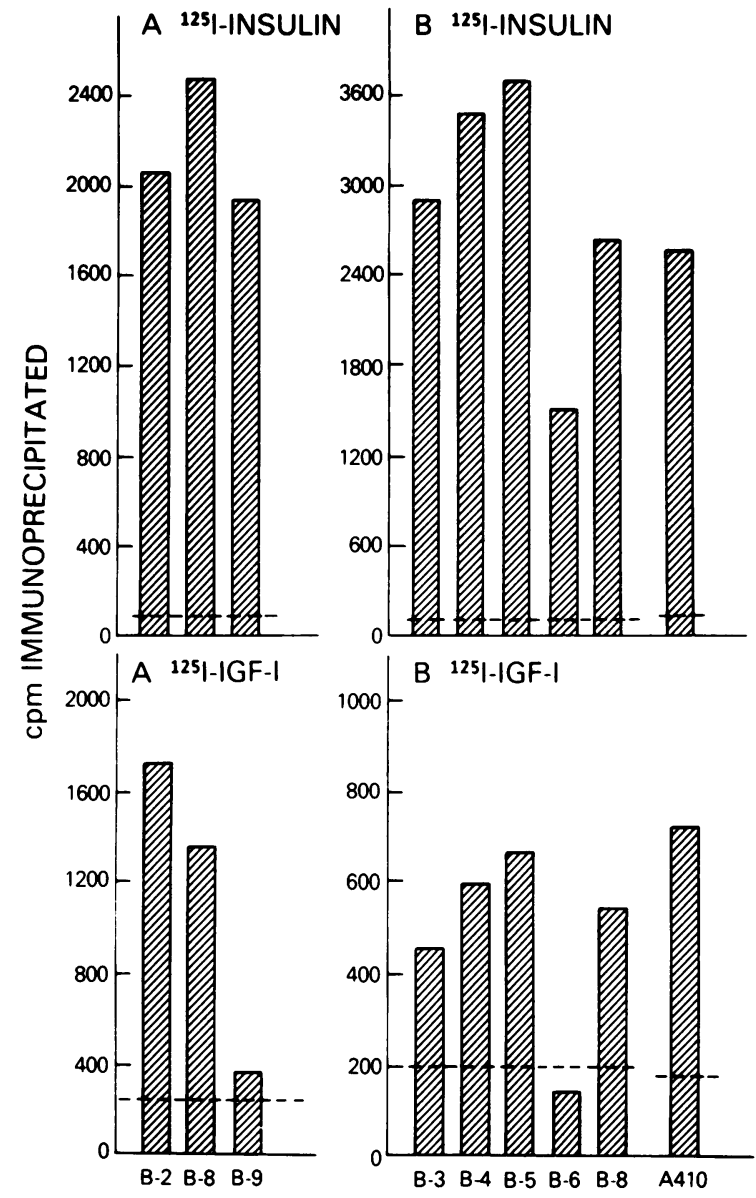

FIGURE 7 Immunoprecipitation of ${ }^{125} \mathrm{I}$-insulin (upper panel) and ${ }^{125}$ I-IGF-I (lower panel) human placental membrane receptor complexes by a panel of human and rabbit sera containing antibodies to the insulin receptor. ${ }^{125} \mathrm{I}$-Insulin and ${ }^{125}$ I-IGF-I were cross-linked to human placental membranes and solubilized in $25 \mathrm{mM}$ Hepes buffer containing $1 \%$ Triton $\mathrm{X}-100$ as described in Methods. Solubilized radiolabeled receptor complexes were incubated with several human sera containing autoantibodies to the insulin receptor (B-2, B-3, B-4, B-5, B-6, B-8, B-9), with rabbit immune serum prepared by injecting purified rat liver insulin receptors (A410), or with control human or rabbit serum (indicated by a dashed line), at 1:100 dilution. The reaction mixtures were immunoprecipitated by adding protein $A$, and the immunoprecipitates washed three times with $25 \mathrm{mM}$ Hepes buffer containing $0.1 \%$ Triton $\mathrm{X}-100$. Immunoprecipitated radioactivity was quantitated in a gamma counter. Results of two experiments ( $A$ and $B$ ) are presented. Serum B-8 was examined at 1:40 dilution in experiment $B$.

Immunoprecipitation of ${ }^{125}$ I-insulin and ${ }^{125}$ I-IGFI receptor complexes by serum from different patients with antiinsulin receptor antibodies and by rabbit antiinsulin receptor serum. We next compared the ability of serum from different Type B patients and from a rabbit immunized with purified insulin recep- tors to immunoprecipitate solubilized placental insulin receptors and IGF-I receptors. As seen in Fig. 7 (upper panel), sera from patients B-2, B-3, B-4, B-5, B-8, and $B-9$, and rabbit immune serum $A 410$, tested at 1:100 dilution, immunoprecipitated 20-36 times more radioactivity in ${ }^{125}$ I-insulin receptor complexes than did the same concentration of control human or rabbit serum. Radioactivity immunoprecipitated by serum B-6 was somewhat lower, but was still 14 times control radioactivity values. Although serum from some Type B patients contains antibodies to insulin in addition to antibodies to receptor, at the serum concentration used (1:100), immunoprecipitation by anti-insulin antibodies is quantitatively significant only for patient B-9.

The ability of the same panel of human and rabbit sera to immunoprecipitate solubilized placental IGFI receptors was examined in the same experiments (Fig. 7, lower panel). In the first experiment, sera B2 and B-8 immunoprecipitated 7.2 and 5.6 times more radioactivity in ${ }^{125}$ I-IGF-I receptor complexes than control serum, whereas serum B-9 was only slightly more effective than control. In the second experiment, sera B-3, B-4, B-5, B-8, and A410 immunoprecipitated 2.3-4.0 times more ${ }^{125}$ I-IGF-I receptor radioactivity than control serum, whereas serum B-6 was slightly less effective than control. These results suggest that most sera with antiinsulin receptor antibodies also possess antibodies that immunoprecipitate placental IGF-I receptors. ${ }^{3}$ Two sera, B-9 and B-6, appeared to be much less reactive with the IGF-I receptor than the insulin receptor.

To evaluate further the differences in the ability of these sera to immunoprecipitate placental insulin receptors and IGF-I receptors, immunoprecipitation was examined at a range of serum concentrations (Fig. 8). At dilutions from $1: 1,000$ to $1: 30$, sera $B-6, B-8$, and B-9 exhibited dose-dependent immunoprecipitation of ${ }^{125}$ I-insulin receptor complexes; sera B-8 and B-9 were similar in potency, whereas serum B-6 was less effective (center panel). By contrast, the same concentrations of sera B-6 and B-9 did not immunoprecipitate ${ }^{125}$ I-IGF-I receptor complexes to a greater extent than control serum (left panel). To exclude any contribution of antiinsulin antibodies to the immunoprecipitation of ${ }^{125} \mathrm{I}$-insulin cross-linked to placental insulin receptors, we examined the ability of these sera to immunoprecipitate insulin receptors of Fao hepatoma cells which had been labeled by surface iodination. As seen in Fig. 8 (right panel), sera B-2, B-6, B-8, and B-9 immunoprecipitated the iodinated insulin receptors to similar extents as the affinity-labeled insulin receptor.

\footnotetext{
${ }^{3}$ Bhaumick et al. (14) have reported that A410 did not immunoprecipitate placental IGF-I receptors. The reason for this discrepancy is not known.
} 


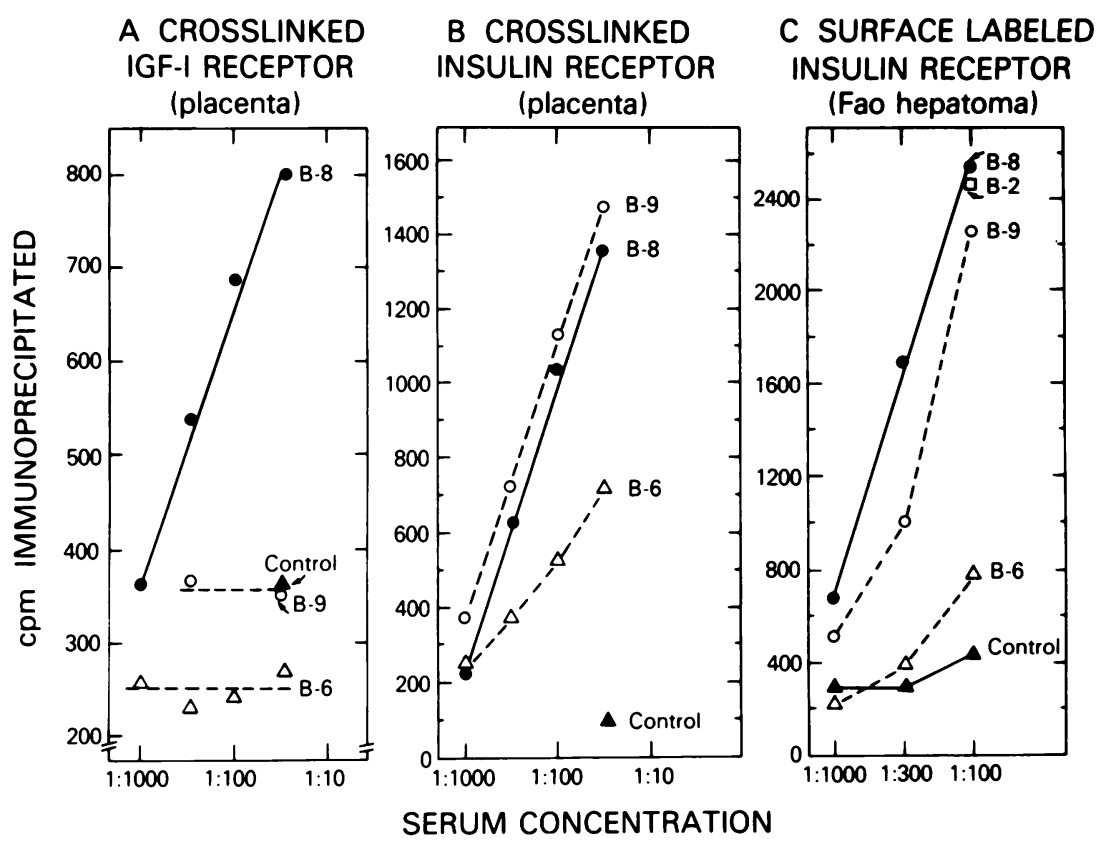

FIGURE 8 Immunoprecipitation of cross-linked ${ }^{125}$ I-IGF-I/placental membrane receptor complexes $(A)$, cross-linked ${ }^{125} \mathrm{I}$-insulin/placental membrane receptor complexes $(B)$, and surfacelabeled insulin receptor complexes from Fao hepatoma cells $(C)$ by different concentrations of sera B-2, B-6, B-8, B-9, and control serum. ( $A$ and $B$ ) Binding of ${ }^{125} I-$ insulin and ${ }^{125} I-I G F-I$ to human placental membranes, cross-linking with DSS, solubilization, and immunoprecipitation were performed as described in the legend to Fig. 7 . In this experiment, $16.8 \%$ of input ${ }^{125} \mathrm{I}$ insulin radioactivity and $33.9 \%$ of input ${ }^{125} \mathrm{I}-\mathrm{IGF}-\mathrm{I}$ radioactivity was precipitable with polyethylene glycol (PEG), presumably representing radioligand complexed to receptor. Of the PEG-precipitable radioactivity, serum B-8 at $1: 30$ dilution immunoprecipitated $78.5 \%$ of ${ }^{125} \mathrm{I}$ insulin receptor complexes $(1,369 \mathrm{cpm})$ and $31.7 \%$ of ${ }^{125} \mathrm{I}-\mathrm{IGF}-\mathrm{I}$ receptor complexes $(804 \mathrm{cpm})$. (C) Hepatoma cells (Fao) were surface iodinated by ${ }^{125} \mathrm{I}$-sodium and lactoperoxidase, and solubilized by Triton X-100 as described in Methods. Insoluble material was removed by ultracentrifugation, and the supernate $(450 \mu \mathrm{l}$ of $10.0 \mathrm{ml})$ was incubated with sera containing antiinsulin receptor antibodies (B-2, B-6, B-8, B-9) or control serum at the indicated dilutions. The reaction mixture was immunoprecipitated by adding protein $A$, and the immunoprecipitates analyzed by SDS-polyacrylamide gel electrophoresis after reduction of disulfide bonds. The radioactivity in the $M_{\mathrm{r}} \sim 135,000$ and $\sim 95,000$ bands was determined by excising the bands from the gels and counting in a gamma counter. Fao cells possess insulin receptors and Type II IGF receptors, but not Type I IGF receptors (reference 21 and Kasuga, M., unpublished results), so that the excised radioactivity represents radioactivity in the insulin receptor.

\section{DISCUSSION}

We have examined the ability of a panel of seven human sera and one rabbit serum containing antibodies to insulin receptors to react with structurally related Type I IGF receptors. Each serum possessed antibodies that reacted significantly with Type I IGF receptors in human placenta and/or cultured lymphocytes. In some instances, however, quantitative differences in reactivity with insulin receptors and Type I IGF receptors were observed.

Serum and IgG from patient B-2, the serum with one of the highest titers of antibodies against insulin receptors, was studied most extensively. IgG B-2 in- hibited binding of ${ }^{125}$ I-insulin and ${ }^{125}$ I-IGF-I to their receptors in human placenta and IM-9 lymphoblast cultures. The concentration dependence for inhibition of binding of both radioligands by IgG B-2 in both systems was similar. Serum B-2 immunoprecipitated both insulin receptor and Type I IGF receptor complexes from human placental membranes as measured by affinity cross-linking techniques. IgG B-2 also immunoprecipitated ${ }^{125}$ I-IGF-I/Type I IGF receptor complexes in the BRL $3 \mathrm{~A} 2$ rat liver cell line, although it did not inhibit ${ }^{125}$ I-IGF-I binding to this receptor. These results suggest that serum B-2 contains antibodies that recognize both rat and human Type I IGF receptors. This serum also contains antibodies (possibly 
the same molecules) that inhibit ${ }^{125}$ I-IGF-I binding to its receptor on human, but not rat, cells.

Immunoglobulins from the sera of four other type $B$ patients inhibited the binding of ${ }^{125} \mathrm{I}$-insulin and ${ }^{125} \mathrm{I}$ IGF-I to the insulin receptors and Type I IGF receptors of human placental membranes and cultured IM-9 lymphoblasts with the same relative potencies: IgG B$5>$ B-8 $>$ B-9 $>$ B- 6 . The concentrations of IgG B-2, B-5, and B-8 producing half-maximal inhibition of ${ }^{125} \mathrm{I}-$ insulin and ${ }^{125}$ I-IGF-I binding to placenta and lymphocytes were similar. Rosenfeld et al. (33) previously reported that serum from a similar insulin-resistant patient also inhibited the binding of insulin and IGFI to IM-9 lymphoblasts at similar concentrations. Moreover, in their patient, antibody titers toward both receptors varied concordantly during the clinical course. By contrast, IgG B-9 and B-6 were much more effective inhibitors of insulin binding than of IGF-I binding, both in placenta (six- to eight-fold difference) and in lymphocytes $(\sim$ threefold difference).

The preceding results suggested that these sera possess autoantibodies that recognize determinants at or near the insulin and IGF-I binding sites. Binding inhibition studies, however, cannot distinguish whether the binding sites for both ligands are present on the same or different proteins. To address this question, ${ }^{125}$ I-insulin and ${ }^{125}$ I-IGF-I placental membrane receptor complexes were cross-linked, solubilized, and immunoprecipitated with a panel of antiinsulin receptor sera. Of eight sera tested, five human sera (B-2, B-3, B-4, B-5, B-8) and one rabbit immune serum (A410) effectively immunoprecipitated the placental Type I IGF receptor in addition to the insulin receptor. The remaining two sera, B-9 and B-6, did not immunoprecipitate Type I IGF receptors to a significant extent. In the case of serum B-9, this appears to reflect a selective impairment in its ability to interact with Type I IGF receptors. Serum B-9 was equipotent with serum B-8 in immunoprecipitating cross-linked or surface iodinated insulin receptors, but was much less reactive than serum B-8 toward the IGF-I receptor. Since serum B-6 exhibited much weaker reactivity toward the insulin receptor, it is not clear whether its low reactivity with the IGF-I receptor also represents a selective difference in specificity.

Our results strongly suggest that serum B-9 recognizes determinants on placental insulin receptors that are not present or accessible on Type I IGF receptors. Since this difference in reactivity was observed in immunoprecipitation as well as inhibition assays, it makes it highly unlikely that insulin and IGF-I binding sites coexist in different domains of the same molecule. This possibility cannot be excluded completely, however, since it is possible that B-9 IgG interacts with a determinant near the IGF-I binding site that becomes inaccessible when ${ }^{125}$ I-IGF-I is cross-linked to the receptor.

We cannot distinguish from our experiments whether a single antibody molecule in each serum recognizes determinants on both insulin and Type I IGF receptors, or whether separate antibody molecules recognizing each of the two receptors coexist in these patients with very high frequency. In favor of the former possibility, two groups $(34,35)$ recently have described four monoclonal antibodies that interact with both human insulin receptors and Type I IGF receptors.

In conclusion, our results seem most compatible with the hypothesis that insulin receptors and Type I IGF receptors are distinct molecules, with similar but not identical structures. The differences may reside in the amino acid sequence or in posttranslational glycosylation. Similar conclusions were reported in a preliminary communication by Jonas et al. (36) using serum from some of the same Type B patients. Together with the homologous subunit structure and overlapping peptide binding specificities, these results suggest that the two receptors may have evolved from a common gene, as presumably occurred for the peptides themselves.

\section{ACKNOWLEDGMENTS}

We wish to thank Dr. Steven J. Jacobs (Wellcome Research Laboratories, Research Triangle Park, NC) for graciously providing rabbit antiserum to purified insulin receptors, and Helen Jenerick for expert secretarial assistance.

\section{REFERENCES}

1. Rinderknecht, E., and R. E. Humbel. 1978. The amino acid sequence of human insulin-like growth factor $I$ and its structural homology with proinsulin. J. Biol. Chem. 253:2769-2776.

2. Rinderknecht, E., and R. E. Humbel. 1978. Primary structure of human insulin-like growth factor II. FEBS (Fed. Eur. Biochem. Soc.) Lett. 89:283-286.

3. Nissley, S. P., and M. M. Rechler. 1978. Multiplication stimulating activity (MSA): a somatomedin-like polypeptide from cultured rat liver cells. Natl. Cancer Inst. Monogr. 48:167-177.

4. Rechler, M. M., J. Zapf, S. P. Nissley, E. R. Froesch, A. C. Moses, J. M. Podskalny, E. E. Schilling, and R. E. Humbel. 1980. Interactions of insulin-like growth factors I and II and multiplication-stimulating activity with receptors and serum carrier proteins. Endocrinology. 107:1451-1459.

5. Hintz, R. L., D. R. Clemmons, L. E. Underwood, and J. J. Van Wyk. 1972. Competitive binding of somatomedin to the insulin receptors of adipocytes, chondrocytes, and liver membranes. Proc. Natl. Acad. Sci. USA. 69:2351-2353.

6. Megyesi, K., C. R. Kahn, J. Roth, E. R. Froesch, R. E. Humbel, J. Zapf, and D. M. Neville, Jr. 1974. Insulin and non-suppressible insulin-like activity (NSILA-s): ev- 
idence for separate plasma membrane receptor sites. Biochem. Biophys. Res. Commun. 57:307-315.

7. Kasuga, M., E. Van Obberghen, S. P. Nissley, and M. M. Rechler. 1981. Demonstration of two subtypes of insulin-like growth factor receptors by affinity crosslinking. J. Biol. Chem. 256:5305-5308.

8. Massagué, J., and M. P. Czech. 1982. The subunit structures of two distinct receptors for insulin-like growth factors I and II and their relationship to the insulin receptor. J. Biol. Chem. 257:5038-5045.

9. Rechler, M. M., and S. P. Nissley. 1983. Receptors for insulin-like growth factors. In Receptors for Polypeptide Hormones. B. I. Posner, editor. Marcel Dekker, Inc., New York. In press.

10. Rechler, M. M., M. Kasuga, N. Sasaki, M. A. De Vroede, J. A. Romanus, and S. P. Nissley. 1983. Properties of insulin-like growth factor receptor subtypes. In Insulinlike Growth Factors/Somatomedins: Basic Chemistry, Biology, and Clinical Importance. E. M. Spencer, editor. Walter de Gruyter Inc., Berlin. In press.

11. Kahn, C. R., K. L. Baird, J. S. Flier, C. Grunfeld, J. T. Harmon, L. C. Harrison, F. A. Karlsson, M. Kasuga, G. L. King, U. C. Lang, J. M. Podskalny, and E. Van Obberghen. 1981. Insulin receptors, receptor antibodies, and the mechanism of insulin action. Recent Prog. Horm. Res. 37:477-538.

12. Pilch, P. F., and M. P. Czech. 1980. The subunit structure of the high affinity insulin receptor: evidence for a disulfide-linked receptor complex in fat cell and liver plasma membranes. J. Biol. Chem. 255:1722-1731.

13. Kasuga, M., E. Van Obberghen, K. M. Yamada, and L. C. Harrison. 1981. Autoantibodies against the insulin receptor recognize the insulin binding subunits of an oligomeric receptor. Diabetes. 30:354-357.

14. Bhaumick, B., R. M. Bala, and M. D. Hollenberg. 1981. Somatomedin receptor of human placenta: solubilization, photolabeling, partial purification, and comparison with insulin receptor. Proc. Natl. Acad. Sci. USA. 78:4279-4283.

15. Chernausek, S. D., S. Jacobs, and J. J. Van Wyk. 1981. Structural similarities between human receptors for somatomedin $\mathrm{C}$ and insulin: analysis by affinity labeling. Biochemistry. 20:7345-7350.

16. Kasuga, M., E. Van Obberghen, S. P. Nissley, and M. M. Rechler. 1982. Structure of the insulin-like growth factor receptor in chicken embryo fibroblasts. Proc. Natl. Acad. Sci. USA.79:1864-1868.

17. Kahn, C. R., J. S. Flier, R. S. Bar, J. A. Archer, P. Gorden, M. M. Martin, and J. Roth. 1976. The syndromes of insulin resistance and acanthosis nigricans. Insulin-receptor disorders in man. N. Engl. J. Med. 294:739-745.

18. Flier, J. S., C. R. Kahn, D. B. Jarrett, and J. Roth. 1976. Characterization of antibodies to the insulin receptor. A cause of insulin-resistant diabetes in man. J. Clin. Invest. 58:1442-1449.

19. Deschatrette, J., E. E. Moore, M. Dubois, D. Cassio, and M. C. Weiss. 1979. Dedifferentiated variants of a rat hepatoma: analysis by cell hybridization. Somatic Cell Genet. 5:697-718.

20. Posner, B. I. 1974. Insulin receptors in human and animal placental tissue. Diabetes. 23:209-217.

21. Massagué, J., L. A. Blinderman, and M. P. Czech. 1982. The high affinity insulin receptor mediates growth stimulation in rat hepatoma cells. J. Biol. Chem. 257:1395813963.
22. Moses, A. C., S. P. Nissley, P. A. Short, M. M. Rechler, and J. M. Podskalny. 1980. Purification and characterization of multiplication-stimulating activity. Insulinlike growth factors purified from rat-liver-cell-conditioned medium. Eur. J. Biochem. 103:387-400.

23. Kahn, C. R., and L. C. Harrison. 1981. Insulin receptor autoantibodies. In Carbohydrate Metabolism and Its Disorders. P. J. Randle, D. F. Steiner, and W. J. Whelan, editors. Academic Press, Inc., New York. 3:279-330.

24. Taylor, S. I., R. F. Dons, E. Hernandez, J. Roth, and P. Gorden. 1982. Insulin resistance associated with androgen excess in women with autoantibodies to the insulin receptor. Ann. Intern. Med. 97:851-855.

25. Jacobs, S., K.-J. Chang, and P. Cuatrecasas. 1978. Antibodies to purified insulin receptor have insulin-like activity. Science (Wash. DC). 200:1283-1284.

26. Ey, P. L., S. N. Prowse, and C. R. Jenkin. 1978. Isolation of pure $\operatorname{IgG}_{1}, \operatorname{IgG}_{2 a}$, and $\operatorname{IgG}_{2 b}$ immunoglobulins from mouse serum using protein A-Sepharose. Immunochemistry. 15:429-436.

27. Marshall, R. N., L. E. Underwood, S. J. Voina, D. B. Foushee, and J. J. Van Wyk. 1974. Characterization of the insulin and somatomedin $\mathrm{C}$ receptors in human placental cell membranes. J. Clin. Endocrinol. Metab. 39:283-292.

28. Sasaki, N., T. Okabe, Y. Imai, H. Matsuzaki, K. Kosaka, K. Wakai, and T. Tsushima. 1981. Basic peptide with insulin-like activity in human serum. Endocrinol. Jpn. 28:157-167.

29. Laemmli, U. K. 1970. Cleavage of structural proteins during the assembly of the head of bacteriophage T4. Nature (Lond.). 227:680-685.

30. Kasuga, M., C. R. Kahn, J. A. Hedo, E. Van Obberghen, and K. M. Yamada. 1981. Insulin-induced receptor loss in cultured human lymphocytes is due to accelerated receptor degradation. Proc. Natl. Acad. Sci. USA. 78:6917-6921

31. Van Wyk, J. J., M. E. Svoboda, and L. E. Underwood. 1980. Evidence from radioligand assays that somatomedin-C and insulin-like growth factor-I are similar to each other and different from other somatomedins. $J$. Clin. Endocrinol. Metab. 50:206-208.

32. Rechler, M. M. 1982. Leprechaunism and related syndromes with primary insulin resistance: heterogeneity of molecular defects. In Membranes and Genetic Diseases. J. Sheppard, V. E. Anderson, and J. Eaton, editors. Alan R. Liss, Inc., New York. 245-281.

33. Rosenfeld, R. G., D. Baldwin, Jr., L. A. Dollar, R. L. Hintz, J. M. Olefsky, and A. Rubenstein. 1981. Simultaneous inhibition of insulin and somatomedin- $C$ binding to cultured IM-9 lymphocytes by naturally occurring antireceptor antibodies. Diabetes. 30:979-982.

34. Kull, F. C., Jr., S. Jacobs, Y.-F. Su, M. E. Svoboda, J. J. Van Wyk, and P. Cuatrecasas. 1983. Monoclonal antibodies to receptors for insulin and somatomedin-C. J. Biol. Chem. 258:6561-6566.

35. Roth, R. A., B. Maddux, K. Y. Wong, D. M. Styne, G. Van Vliet, R. E. Humbel, and I. D. Goldfine. 1983. Interactions of a monoclonal antibody to the insulin receptor with receptors for insulin-like growth factors. Endocrinology. 112:1865-1867.

36. Jonas, H. A., R. C. Baxter, and L. C. Harrison. 1982. Structural differences between insulin and somatomedin-C/insulin-like growth factor-1 receptors revealed by autoantibodies to the insulin receptor. Biochem. Biophys. Res. Commun. 109:463-470. 